\title{
Comparison of health-related quality of life in children with normal hearing and those with cochlear implant at age of 4-6 years
}

\author{
N oreen Anwar ${ }^{1}$, M unazza H ayat ${ }^{2}$, Atia-ur-Rehman ${ }^{3}$, T ayyaba D awood ${ }^{1}$, Adnan Anwar ${ }^{4}$, W aris Ali ${ }^{5}$ \\ ${ }^{1}$ C linical Audiologist, EN T U nit, Audiology Department SG RH/FJM U L ahore, ${ }^{2}$ L ecturer Clinical Psychologist, U niversity of L ahore, ${ }^{3} \mathrm{Clinical}$ \\ Audiologist, Civil H ospital Bahawalpur, ${ }^{4} A$ ssistant Professor SL P, U niversity of $L$ ahore, ${ }^{5} \mathrm{C}$ linical Audiologist, $U$ niversity of $L$ ahore \\ Correspondence to: T ayyaba D awood, E mail: taibadawood3@gmail.com
}

\begin{abstract}
Background: $\mathrm{H}$ earing impairment during early life years have profound negative consequences on linguistic output, educational, psychosocial and physical functioning. Auditory perception plays a key role in the development of child. Severely hearing-impaired children receiving cochlear implant $(\mathrm{Cl})$ before the age of speech and language acquisition may enjoy their quality of life similar to their normally hearing peers. Considering the beneficial effects of $\mathrm{Cl}$ on quality of life of hearing-impaired child, it is evident to properly investigate the similarity in life quality of children with $\mathrm{Cl}$ and their normal hearing mates of same age group.

Patients and Method: This comparative cross-sectional study was conducted on parents of 50 children, who were allocated in two equal groups by purposive sampling. T he questionnaire was administered by interviewing the parent participants using a validated quality of life questionnaire of $\mathrm{C}$ hildren for $\mathrm{P}$ arents and findings were compared with the responses from parents of normal hearing children. Responses from both the groups were analyzed by independent sample t-test.

Results: Parents of Cochlear Implanted children rated their children's Health Related Quality of Life positively. All the sub domains showed the similar results except self-esteem. Findings suggest that normally hearing children had better self-esteem than $\mathrm{Cl}$ children. $\mathrm{N}$ o significant difference was found between overall $\mathrm{H}$ ealth Related $\mathrm{Q}$ uality of $\mathrm{L}$ ife of Cochlear I mplanted children and their normally hearing peers.

Conclusion: O verall health related quality of life of children with cochlear implant is similar to that of normal hearing peers of same chronological age.

Keywords:
\end{abstract}

$\mathrm{N}$ ormal hearing; $\mathrm{H}$ earing loss; Q uality of L ife; C ochlear Implant

\section{INTRODUCTION}

$\mathrm{H}$ earing plays a key role generally for safety, awareness and particularly for the development of speech, language and communication skills which is important for day to day conversations. H earing impairment during infancy and early life years may have primary and secondary consequences. Primarily, decreased hearing acuity effects speech and language development because child is unable to receive or partially receive hearing stimulus, thus the linguistic output will be deteriorated. Secondary consequences include effected general, social, psychological and physical functioning and hence resulted in overall disrupted Q uality of Life $(\mathrm{Q} \text { oL })^{1}{ }^{1}$

Conflict of interest: $T$ he authors declared no conflict of interest exist.

Citation: Anwar N, Hayat M, Rehman A, Dawood T, Anwar A, Ali W. Comparison of health-related quality of life in children with normal hearing and those with cochlear implant at age of 4-6 years. J Fatima Jinnah M edical U niv. 2019; 13(4): 175-179.

D OI: https://doi.org/10.37018/jfjmu.673
Hearing impairment can be classified as conductive, mixed, sensorineural and central type. ${ }^{2}$ $\mathrm{H}$ earing loss $(\mathrm{HL})$ can also be classified in degrees depending on its severity, it may be slight to profound. From $16 \mathrm{~dB}$ to $25 \mathrm{~dB}$ it is considered as slight $\mathrm{HL}, 26 \mathrm{~dB}$ $-40 \mathrm{~dB}$ mild, $41 \mathrm{~dB}$ to $55 \mathrm{~dB}$ moderate, $56 \mathrm{~dB}-70 \mathrm{~dB}$ moderately severe, $71 \mathrm{~dB}-90 \mathrm{~dB}$ severe and $91 \mathrm{~dB}$ to onwards it is termed as profound $\mathrm{HL} .^{3}$ For mild to moderately severe deficit, hearing aids can provide an effective management. But when $\mathrm{HL}$ reach at severe to profound level, the hearing aids become ineffective, these patients are poor candidates of hearing aids because via hearing aids they get only limited benefit in terms of sound awareness and are unable to perceive and comprehend speech sounds. ${ }^{4}$ Thus, Cochlear Implant (CI) is a treatment of choice for patients having severe to profound sensorineural $\mathrm{HL} .^{5}$

$\mathrm{Cl}$ reaps a large number of benefits by providing opportunity to the congenitally deaf children who have spare VIII cranial nerve (vestibulocochlear nerve) and those who have severe to profound hearing 
impairment. $^{6}$ These candidates can develop communication skills similar to hearing mates of same age specially when $\mathrm{H} \mathrm{L}$ detected and treated in early life years i.e. before 2 years of age. ${ }^{7}$

The most widely confirmed treatment of choice for profound $\mathrm{HL}$ in infants is $\mathrm{Cl}$. Restoration of hearing ability before the age of speech and language acquisition, with the help of CIs significantly improve the communication skills but the results may vary based on certain factors i.e. chronological age at implantation, duration of $\mathrm{HL}$, general developmental potential, environment for socialization and support to the child from the family and relatives. ${ }^{8,9} \mathrm{Cl}$ not only influences communication skills but also psychological and social well-being and hence improves $\mathrm{Q} O \mathrm{~L} .{ }^{8}$

Q oL as the position of the hearing impaired child based on parental perception about life, related to the culture and value system of the society of child, including all domains of $\mathrm{Q}$ oL i.e. physical, educational, functional social and emotional. ${ }^{10}$ Study of $\mathrm{QOL}$ in general can be estimated to be 'child centered' in terms of child's happiness, capacity to form friendships and independence of functions and 'family centered' i.e. parents' level of anxiety and disruption of family due to hearing impairment of their child. ${ }^{11}$

Evaluating the $\mathrm{H}$ ealth Related Quality of Life (HRQ oL) of hearing impaired candidates is a useful way to make evident all the positive outcomes obtained by $\mathrm{Cl}$ including psychosocial and academic benefits furthermore the professional impact of $\mathrm{Cl}$ on communication performance of $\mathrm{Cl}$ bearers. ${ }^{12} \mathrm{Cl}$ surgery was started in August 2000 in Pakistan but unfortunately no research on $\mathrm{Q}$ oL of $\mathrm{Cl}$ children has been done so far. ${ }^{13} \mathrm{~T}$ his study is aimed to compare the performances and improvements in Q oL of implanted children versus their normally hearing peers by interviewing the parents of the children of both groups to initiate an effort to fill the gap in the literature.

\section{PATIENTS AND METHODS}

T his comparative cross-sectional study was conducted from 28 ${ }^{\text {th }}$ D ecember 2018 till 28 $8^{\text {th }}$ September 2019 in the Audiology Centre and the Research Institute $L$ ahore for recruiting the parents of implanted children, whereas data for children with $\mathrm{N}$ ormal $\mathrm{H}$ earing has been collected from Askari Public School L ahore C antt.

Parent participants of 50 children based on their child's profile, either mother or father, where necessary both parents were included in the study to take their perceptions about health-related quality of life of their children with cochlear implant and those with normal hearing by formally questioning the parents of both groups. Ethical approval was taken from ethical committee. A detailed consent was taken from all of the parent participants before including them in the study.

Parents of those cochlear implanted children were included in the group A whom children's ages were 4-6 years, their children had documented severe to profound sensorineural hearing loss, received their unilateral cochlear implants before three years of age, so that those children must have at least three years of experience with the implant and who did not have any additional disability except hearing impairment.

G roup B consisted of Parents of children with normal hearing. They participated in this study by completing the questionnaire in annual parents-teachers meeting. Researcher personally went there to get the questionnaire filled. $\mathrm{N}$ ormal hearing sensitivity of their children was reported by the parents themselves. The ages of the children of group $B$ parents were also between 4-6 years.

Data was collected from parents using an internationally validated Kiddy KINDL parents' (Revised version) questionnaire. Kiddy $\mathrm{KINDL}^{\mathrm{R}}$ questionnaire was consisted of 24 statements divided into six health related quality of life domains i.e. physical well-being, emotional well-being, self-esteem, family, friends and school performance and some important questions comprises of 22 statements.

Participants responded on 5-point Likert scale as never, seldom, sometimes, often and all the times. All the participants completed the questionnaire with $100 \%$ response rate. The scale was translated into U rdu so that target population can easily understand the questionnaire. For this purpose, permission from the KINDL organization was taken and the questionnaire was translated into Urdu by following MAPI's guidelines to check reliability and validity of the translated version of the questionnaire.

For measuring the HRQ oL from both the groups of parents, the data was collected on questionnaire proformas and was analyzed using SPSS version 20 with relevant statistical tests. Frequency and percentages were calculated for quantitative data analysis, Independent sample t test was used to compare the outcomes between the two groups.

\section{RESULTS}

A total of 50 parent participants were enrolled in the study, divided into two groups, 25 in group A consisted of parents of congenitally hearing-impaired children who had Cochlear Implant $(\mathrm{CI})$ in early life and 25 in 
T able 1. Independent sample t test for total health-related quality of life

\begin{tabular}{lccc}
\hline T otal H RQ oL & M ean \pm SD & $t$ & p-value \\
\hline C hildren with normal hearing & $92.28 \pm 10.8$ & 0.424 & 0.674 \\
\hline Children with cochlear implant & $91.1 \pm 7.55$ & & \\
\hline
\end{tabular}

T able 2. Independent sample t-test for health-related quality of life sub domains of K iddy K indl ${ }^{R}$ Parents' questionnaire

\begin{tabular}{lccc}
\hline T otal health related quality of life & M ean \pm SD & t & p-value \\
\hline Physical well being & $0.28 \pm 0.495$ & .565 & 0.575 \\
\hline E motional well being & $1.32 \pm 0.70$ & 1.875 & 0.067 \\
\hline Self esteem & $1.84 \pm 0.69$ & 2.662 & 0.011 \\
\hline Family & $0.40 \pm 0.45$ & .887 & 0.380 \\
\hline Social contacts & $-0.44 \pm 0.69$ & -.631 & 0.531 \\
\hline School & $0.56 \pm 0.645$ & .868 & 0.390 \\
\hline Important questions & $-0.2 \pm 1.49$ & -.134 & 0.894 \\
\hline
\end{tabular}

group B, parents of children who had normal hearing. The M inimum age of implantation of child was 1.2 years and maximum age was 3 years whereas mean age of implant was 2.1 years with the standard deviation of 0.57635 . There were total 50 number of candidates included in the study comprising of 29 male (58\%) and 21 females (42\%).

According to the responses from the parents of both group of children the $M$ ean health related quality of life (H RQ oL) of children who had normal hearing and children having cochlear implants with standard deviations in the brackets were 92.20 (10.84) and 91.16 (7.55) respectively as shown in T able 1.

As appeared in the table 2 for measuring $\mathrm{HRQ}$ oL of both the normal hearing and cochlear implant group at different sub domains independent sample t test was used. $\mathrm{N}$ o significant difference was found between both the groups at physical well-being $(p>0.05)$, emotional well-being $(p>0.05)$, family $(p>0.05)$, social contacts $(p>0.05)$, school sub domains. Significant difference was found only at Self-esteem sub domain $(p<0.05)$.

As per the answers by the parents on total $\mathrm{HRQ}$ oL of both the $\mathrm{N}$ ormally $\mathrm{H}$ earing $(\mathrm{NH})$ and Cochlear Implanted groups on all sub domains showed no significant difference except self-esteem $(p<0.05)$ ( $M=1.84000, S D=69109$ ). Parents of $\mathrm{Cl}$ users perceived that their children have less self-esteem while the Parents of $\mathrm{N} \mathrm{H}$ children responded better.

T able 3 also summarizes the findings for all sub domains of quality of life of children of both parents depicting approximately equal quality of life regarding physical and emotional wellbeing, family, school and social contacts of their children excluding self-esteem that is less in cochlear implanted children.

\section{DISCUSSION}

This study is based on effectiveness of cochlear implant (CI) in terms of Improvement of Q uality of life $(\mathrm{Q} o \mathrm{~L}$ ) of profoundly deaf children at least three years post implantation. A comprehensive, sensitive, reliable and internationally validated $Q$ oL generic Kiddy-KIN D L ${ }^{R}$ (3-6 years) questionnaire was used for this purpose. $T$ he study population of this thorough investigation was too young to answer a questionnaire therefore based on observation, views and experiences of parents this typical health-related Quality of life (HRQOL) questionnaire was chosen. ${ }^{14}$ Parents positively rated overall $\mathrm{HRQ}$ OL of their children who received $\mathrm{Cl}$ in early life years i.e. before 3 years of age, because of their extreme involvement in health care of their children. $\mathrm{Cl}$ children included in this study had three years of device experience and implanted at the age of (1-3 years). At the time of data collection, they reached to the age ranges between 4 and 6 years. Results suggested that children with $\mathrm{Cl}$ enjoy health related $\mathrm{Q}$ oL similar to that of normal hearing $(\mathrm{N} \mathrm{H})$ mates of same age because we found no significant difference between $\mathrm{HRQ}$ oL of both groups of same chronological age except the domain of self-esteem where $p$ value was less than 0.05 .

In agreement with many international researchers this study finds out that Parents responded $\mathrm{HRQ}$ oL of their $\mathrm{Cl}$ children positively on school performance and physical and emotional well-being but self-esteem were less positively rated. ${ }^{15} \mathrm{~T}$ otal $\mathrm{Q}$ oL score were similar to that of $\mathrm{NH}$ group. On statistical analysis there was no significant difference were found in overall health related $\mathrm{Q}$ oL of $\mathrm{C}$ hildren with $\mathrm{Cl}$ or $\mathrm{Cl}$ group $(\mathrm{M}=82.8$, $\mathrm{SD}=9.7)$ and children with $\mathrm{NH}$ or $\mathrm{N} \mathrm{H}$ group $(\mathrm{M}=80.8$, $\mathrm{SD}=10.3$ ) whereas $(t=0.81, p=0.42$ ).

Results shown from another study are in accordance with the findings of this study stating the mean age of Cochlear Implantation was $2.4 \pm 2.25$ years and mean duration of implant usage was $3.7 \pm 1.4$ years. ${ }^{16}$ Q oL was measured on eight sub domains, out of which 5 were consistent with our measurements (social outcomes, general functioning, well-being, self-esteem and school performance). $75 \%$ of the parents reported that confidence of their children has been boosted up, $67.9 \%$ rated increased confidence than ever before, 96.5\% responded that their children remained happy and $50 \%$ of the children were able to make new friends and got to interact with others easily after Cochlear Implantation as their normal age mates.

Results from another supporting study are consistent with our study on several domains of $\mathrm{Q}$ oL in which $83.9 \%$ parents rated better general feelings of their children, $84.5 \%$ parents revealed that their children were able to do his/her work independently as his/her mates and $85.8 \%$ marked improved self- 
Table 3. Health-related quality of life for both groups on all sub domains

\begin{tabular}{lcc}
\hline Sub domains & $\begin{array}{c}\text { N ormal hearing } \\
{[\text { M ean } \pm \text { SD }]}\end{array}$ & $\begin{array}{c}\text { Cochlear implant } \\
{[\text { M ean } \pm \text { SD ] }}\end{array}$ \\
\hline Physical wellbeing & $5.44 \pm 2.0$ & $5.16 \pm 1.4$ \\
\hline Emotional wellbeing & $5.6 \pm 2.3$ & $6 \pm 2.6$ \\
\hline Self esteem & $12.2 \pm 2.4$ & $10.4 \pm 2.4$ \\
\hline Family & $8.4 \pm 1.5$ & $8.08 \pm 1.6$ \\
\hline Social contacts & $9.8 \pm 2.5$ & $10.32 \pm 2.3$ \\
\hline School & $9.3 \pm 2.6$ & $8.76 \pm 1.7$ \\
\hline Important questions & $42.2 \pm 5.5$ & $42.44 \pm 5.01$ \\
\hline
\end{tabular}

confidence of their children. ${ }^{17}$ According to $90.01 \%$ parents, their children were fully able to indulge in conversations and they were more talkative than before, $85.7 \%$ parents thought that their children have become more socialized. O verall $\mathrm{Q}$ oL of children was improved after Cochlear Implantation comparable to their $\mathrm{N} \mathrm{H}$ fellows. ${ }^{18}$

T. Razafimahefa-Raoelina and coauthors reported in their research on 32 children with pre lingual $H \mathrm{~L}$, implanted at the mean age of 22 months, similar as the mean age of implantation ( $M=2$.1years) of our sample population. $T$ he results of responses from 32 parents on all key domains of $\mathrm{Q}$ oL at $\mathrm{K}$ idscreen-27 questionnaire were differed from results from parents of $\mathrm{NH}$ peers, showing contradictory findings to our research. ${ }^{19}$

Rachel and coauthors conducted a research in 2013 on three groups. (a) Children with $\mathrm{Cl} / \mathrm{Cl}$ group (b) Children with $\mathrm{NH} / \mathrm{NH} 1$ group (c) Children with $\mathrm{NH}$ and higher financial status/ $\mathrm{N} \mathrm{H} 2$ group. In contrast to the findings of our research study, there were highly significant differences were found between $\mathrm{Cl}-\mathrm{NH} 1$ and $\mathrm{Cl}-\mathrm{NH} 2$ groups on the basis of parents' observations. Parents of $\mathrm{CI}$ children rated overall health related $\mathrm{Q}$ oL of their children lower than $\mathrm{NH} 1$ group and higher than $\mathrm{NH} 2$ groups on various $\mathrm{HRQ}$ oL sub domains. ${ }^{20}$

$V$ arious explanations may account for this contrast in results. O ne reason is that parents of $\mathrm{Cl}$ children may underestimated their children' QoL because the results of second hypothesis of both these studies suggested that children self-reported $\mathrm{Q}$ oL was much better on all domains than their parents' perspectives. Moreover, $\mathrm{N} \mathrm{H} 1$ group in study of Rachael and colleagues possess high financial status, better living environments and higher qualification of parents than parents of $\mathrm{Cl}$ children, thus health related $\mathrm{Q}$ oL scores of this group were higher from both other groups ( $\mathrm{N} \mathrm{H} 2$ and $\mathrm{Cl}){ }^{21}$ Thus, it can be concluded that profoundly deaf children if implanted before the age of speech and language acquisition can enjoy $\mathrm{QOL}$ as $\mathrm{NH}$ mates of same chronological age.
This study had some limitations as well. This study provided parental perspectives about their $\mathrm{Cl}$ children's health related QoL via a general QoL measuring questionnaire. Further studies may incorporate a $\mathrm{Cl}$ specific $\mathrm{Q}$ oL questionnaire consisting of open-ended questions from parents and their children as well to obtain more in-depth information regarding $\mathrm{Q}$ oL of children with $\mathrm{C} I \mathrm{~s}$.

\section{CONCLUSION}

This study revealed that there is no significant difference in the health-related quality of life of investigated groups, the cochlear implanted children and normal hearing children of same chronological age, as it is evident from the parental perception of both groups. It is concluded that profoundly hearingimpaired children, if implanted before the age of speech and language acquisition they can enjoy their life as their normal hearing peers.

\section{REFERENCES}

1. Varghese AV, Martina AT. Quality of life in children with cochlear implants: effect of implant age on general functioning. Int J Sci Rsrch. 2018; 6(5):111-13.

2. Gifford $K A, H$ olmes $M G$, Bernstein $H H$. Hearing loss in children. Pedi Rev. 2009; 30(6):207-15.

3. D hingra PL. Diseases of Ear, N ose and Throat \& $\mathrm{H}$ ead and $N$ eck Surgery, $7^{\text {th }}$ ed. India: Reed Elsevier; 2017:389.

4. Papsin BC, Gordon KA. Cochlear implants for children with severe-to-profound hearing loss. $\mathrm{N}$ ew Eng J Med. 2007; 357(23):2380-7.

5. Forli F, Turchetti G, Giuntini G, Bellelli S, Fortunato S, Bruschini L, Barillari MR, Berrettini S. Cochlear implant in prelingually deafened oralist adults: speech perception outcomes, subjective benefits and quality of life improvement. Acta O tor I tal. 2017; 37(5):416-19.

6. Svirsky MA, Teoh SW, N euburger H. Development of language and speech perception in congenitally, profoundly deaf children as a function of age at cochlear implantation. Audio N eur. 2004; 9(4):224-33.

7. Leigh J, D ettman S, Dowell R, Briggs R. Communication development in children who receive a cochlear implant by 12 months of age. $\mathrm{O}$ tol $\mathrm{N}$ eur. 2013; 34(3):443-50.

8. L in FR, Niparko JK. M easuring health-related quality of life after pediatric cochlear implantation: a systematic review. Int J Pedi O tol. 2006; 70(10):1695-706.

9. Fortunato- $T$ avares $T$, Befi- $L$ opes $D$, Bento $R F$, Andrade $C R$. Children with cochlear implants: communication skills and quality of life. Braz J otol. 2012; 78(1):15-25.

10. Sach TH, W hynes DK. Pediatric cochlear implantation: The views of parents. Int J Audi. 2005; 26(3):125-28.

11. Kumar R, W arner-Czyz A, Silver CH, Loy B, Tobey E. American parent perspectives on quality of life in pediatric cochlear implant recipients. Ear H ear. 2015; 36(2):269-78.

12. Sousa AF, Couto MI, M artinho-Carvalho AC. Q uality of life and cochlear implant: results in adults with postlingual hearing loss. Braz J of otol. 2018; 84(4):494-9.

13. Stacey $P C$, Fortnum $H M$, Barton GR, Summerfield $A Q$. $\mathrm{H}$ earing-impaired children in the $U$ nited Kingdom, I: Auditory 
performance, communication skills, educational achievements, quality of life, and cochlear implantation. Ear Hear. 2006; 27(2):161-86.

14. Ravens-Sieberer, U . \& Bullinger, M. N ews from the KIN D L Q uestionnaire-A new version for adolescents: Q uality of Life Research. 1998b; 4(7);653-57.

15. Byčkova J, Simonavičienè J, Mickevičienè V, Lesinskas E. Evaluation of quality of life after paediatric cochlear implantation. Acta M edica L ituanica. 2018; 25(3):173-77.

16. Yorgun $M$, Sürmelioğlu Ö, T uncer Ü, T arkan Ö, Özdemir S, Çekiç $E$, Çetik $F, K_{1}$ roğlu M. Quality of life in pediatric cochlear implantations. J Int Adv O tol. 2015;11(3):218-20.

17. Razafimahefa-Raoelina $T$, F arinetti $A, N$ icollas $R, T$ riglia JM, Roman S, Anderson L. Self-and parental assessment of quality of life in child cochlear implant bearers. Eurp Annl O torl. 2016; 133(1):31-5.
18. Yorgun M, Sürmelioğlu Ö, T uncer Ü, T arkan Ö, Özdemir S, Çekiç E, Çetik F, K ıroğlu M. Quality of life in pediatric cochlear implantations. J Int Adv O tol. 2015;11(3):218-20.

19. N ecula $V$, C osgarea $M, N$ ecula SE. H ealth-related quality of life in cochlear implanted patients in Romania. Int J Pedi 0 tol. 2013;77(2):216-22.

20. M eserole RL, C arson CM, Riley AW, $W$ ang $N Y, Q$ uittner $A L$, Eisenberg LS, Tobey EA, Francis HW, Niparko JK. Assessment of health-related quality of life 6 years after childhood cochlear implantation: Quality of Life Research. 2014; 23(2):719-31.

21. W arner-Czyz AD, Loy B, Roland PS, T ong L, T obey EA. Parent versus child assessment of quality of life in children using cochlear implants. Int J Pedi O tol. 2009; 73(10):1423-9. 